\title{
Improving the publication visibility of Ecuador's higher education system
}

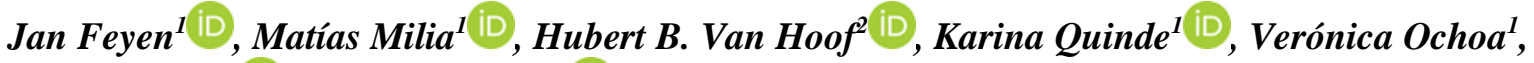 \\ Victoria Abril $^{1}$ (D), Jaime Bojorque ${ }^{1}$ (D) \\ 1 Dirección de Investigación, Universidad de Cuenca, Av. 12 de Abril, Cuenca, 10150, Ecuador. \\ 2 College of Health and Human Development, Pennsylvania State University, University Park, PA \\ 16802, USA.
}

Autores para correspondencia: jan.feyen@ucuenca.edu.ec, matias@milia.net, hbv1@psu.edu, karina.quinde@ucuenca.edu.ec, veronica.ochoa@ucuenca.edu.ec, victoria.abril@ucuenca.edu.ec, jaime.bojorque@ucuenca.edu.ec

Fecha de recepción: 11 de mayo 2016 - Fecha de aceptación: 8 de noviembre 2016

\begin{abstract}
This article reports on a comparative study between the publication productivity of Ecuador's leading Higher Education Institutions (HEIs) (as reported in the SCOPUS journal/proceedings database; https://www.elsevier.com/solutions/scopus) and the publication efforts of similar universities in SouthAmerica and Western Europe when those universities converted from a "teaching-only" to a "teaching and research" focus. The authors highlight the causes of Ecuador's research and publication paucity and suggest remedial strategies which focus on adjusting the profile and activities of Ecuador's HEIs to better meet the skills gap in the 21st century economy; economy driven by innovation and knowledge. The article proposes that Ecuador's HEIs make teaching collaborative and more affordable, stimulate faculty to examine society-relevant problems in teams, educate and encourage faculty to publish in peer-reviewed journals and enhance effectiveness and efficiency so that a stronger teaching-researchservice nexus emerges; all even though Ecuador has entered a period of economic hardship with dwindling funds for higher education.
\end{abstract}

Keywords: Ecuador, Higher Education Institutes, publication visibility, causal factors, remedial actions.

\section{RESUMEN}

Este artículo reporta un estudio comparativo entre el producto de publicaciones científicas de las principales Instituciones de Educación Superior (IES) en Ecuador (tal como se indica en la base de datos de revistas/actas de SCOPUS; https://www.elsevier.com/solutions/scopus) con el récord de publicaciones de Universidades en América del Sur y Europa Occidental cuando estas cambiaron de un enfoque de "enseñanza" hacia uno de "enseñanza e investigación". Los autores discuten las causas del bajo nivel de investigación y el reducido número de publicaciones en las IES ecuatorianas; y proponen estrategias correctivas para ajustar el perfil y las actividades de las IES del Ecuador con el objeto de contrarrestar el déficit de habilidades necesarias para impulsar la economía del siglo XXI; economía impulsada por la innovación y el conocimiento. El artículo propone que es necesario que las IES ecuatorianas faciliten el aprendizaje colaborativo y flexible, que aliente a los profesores a formar equipos de trabajo para examinar e investigar los problemas relevantes de la sociedad; además, de incentivar que estos difundan los resultados de sus investigaciones en revistas con revisión por pares; de este modo, se logrará mejorar la eficacia y la eficiencia de las IES ecuatorianas al crear un nexo fuerte entre enseñanza-investigación-vinculación. Labor indispensable, a pesar de que Ecuador ha entrado en un período de dificultades económicas con la subsecuente disminución de los fondos para la educación superior.

Palabras clave: Ecuador, Institutos de Educación Superior, visibilidad de la publicación, factores causales, acciones correctivas. 


\section{INTRODUCTION: THE REASONS WHY FACULTY PUBLISHES}

In today's academic environment it is an assumption that scholars disseminate the results of their research effort to the academic community and society at large. By dissemination, scholars gain recognition in the discipline, which facilitates interaction with other scientists who are active in the same field and helps in acquiring grants for future research efforts. The publication of research results is also done to gain promotion and tenure and it helps the HEI to improve its stature and ranking among its peer institutions. Publication of results shows that something meaningful was accomplished and it contributes to the progress of science in general, and the advance in each domain. As stated by Herxheimer (1993), research results are public property, not private, and ought to be shared with the society that funds and supports the research. Chalmers (1990) goes one step further and states that the underreporting of research is a form of academic misconduct because it distorts publicly available evidence and ultimately amounts to a waste of resources.

In developed countries with mature, research-based universities, faculty members face ever increasing pressure to publish to be promoted and raise the institution's standing. Whereas a publication record is often regarded as a proxy of the quality of a researcher or institution, it is not an assurance of quality, because much depends on the impact factors of the journals in which material is published and on related citation metrics (Kaur et al., 2015). At times, the pressure to publish becomes so high that fraud in the collection and manipulation of experimental data becomes a threat, to the extent that scientists will fabricate data and use it as the basis for the development of their research papers. It is not uncommon for editors of journals to have to retract published articles when fraud was discovered after publication (Jha, 2012) and the issue that has arisen recently is whether the pressure to publish has not given rise to unhealthy competition between faculty, rather than further a cooperative and collaborative scientific environment (Fang \& Casadevall, 2015).

Whereas the publication pendulum in leading HEIs operating under the "research and teaching" paradigm has swung to an almost over-production of, at times, low-quality publications, it has not yet swung in the same direction in countries with underdeveloped HEIs that still adhere to the "teachingonly" paradigm. Their low publication records are a direct outflow of the dilemmas and conflicts that are experienced by an academic community that is confronted with heavy teaching loads, low research and publication skills, low remuneration, and the temptation for professors to step into consultancy to improve one's standard of living (Kilonzo \& Magak, 2013).

Apart from scholars in Brazil, India and China (Gaillard, 2000) the publication visibility of researchers in the less developed and emerging economies of the world has not significantly increased in recent decades. Some of the prominent reasons for this publication shortage are: (a) the overall low research capacity of local researchers and the often inadequate research infrastructure; (b) the local journals in which scholars publish have a low impact and lack academic recognition and prestige; (c) the research by scholars studying abroad for master's or doctoral degrees researching topics on their territory is published in international peer-reviewed journals and seldom contributes to the publication visibility of the home country; (d) results of research projects in which local and overseas scientists participate and which are funded by international agencies often end up in peer-reviewed journals, but it is not uncommon that local scholars who cooperated in those projects are neglected when it comes to publishing and publication credentials; and (e) researchers of LDCs even when they publish in top journals are cited far less often than authors from OECD countries (Cano, 1993; Dahdouh-Guebas et al., 2003; Erftemeijer et al., 2001; Gaillard, 1991; Gibbs, 1995; Raina \& Habib, 1994).

Besides contributing to knowledge in general, the publication of solid research results is also needed to upgrade and improve teaching and learning (Clark, 1997). A modern university professor should keep track of the literature in his/her field and use published materials as the basis for the actualization of the materials that he/she presents to students. Professors should use published materials as ad-hoc documentation to course syllabi so that students, preferably from the moment they start their undergraduate careers, learn how to read and analyze research papers and understand how research is conducted and how articles are structured and presented. This prepares them for the moment they are expected to conduct a thesis research project on their own and summarize their findings. By doing so, students will develop a critical attitude to reading, speaking and writing coherently, skills which 
graduates should increasingly possess in today's workforce. This approach will not only benefit students, but also keep professors alert of new findings, enhance the nexus between teaching and research, and in turn create a more fertile breeding ground for future researchers and professors. If undergraduate students have never read a scientific article or done a review of literature, how can they be expected to move on and become successful graduate students in international academic environments where expectations and assumptions about their university education are high?

Against the changing and increasingly competitive international structure of science and publication (which has also led to an increase in competition between true science and the seemingly unbridled growth in the number of indexed journals (Fang \& Casedevall, 2015)), this article attempts to shed light on the publication visibility of Ecuador's HEIs by using their publication records in the SCOPUS journals/proceedings database. It quantifies the shortfall in scientific writing in comparison to universities in South America and Western Europe at the time that research at those universities was emerging and identifies some of the causes of the backlog in science and publication visibility. It concludes by offering recommendations that might help Ecuador's HEIs improve their publication visibility.

\section{MEASURING THE INTERNATIONAL PUBLICATION VISIBILITY OF ECUADOR's HEIs}

It is virtually impossible to construct a complete and accurate picture of the publication output of Ecuador's public and private universities and research institutes due to a lack of a National Digital Author Identifier system in the country. In anticipation of the development of such a system, HEIs have recently started to develop their own repositories of scholarly papers, datasets, administrative documents and course related information which can be consulted online. Getting a global picture of the publication output of Ecuador's HEIs would require visiting each of the repositories of the 25 public, 9 co-financed and 33 private universities and the 23 research institutions in the country. Unfortunately, most of these repositories are incomplete, since research units and authors not always provide timely information on their activities, or cuts in budgets, and/or negligence and turnover of the library staff cause repositories to be incomplete and outdated. Even though such an analysis would provide interesting information, the extent of such an endeavor falls beyond the scope of this study.

An alternative way to investigate the publication output of Ecuador's HEIs is an analysis of the SCOPUS abstract and citation database, which enables the collection of publication records at the levels of the individual authors, the institution and a country. The main advantage of using SCOPUS information is that the data derived from SCOPUS is uniform, internationally accepted, and provides insight into research output in peer-reviewed, international, journals. The disadvantage in analyzing the SCOPUS database, even though it includes information of over 21,500 peer-reviewed journals from more than 5,000 international publishers and more than 113,000 books, is that it does not permit reconstructing a complete picture of the publication patterns of faculty and researchers at the local, regional and national levels. However, analysis of the SCOPUS database enables assessment of the publication output of Ecuador's HEIs in peer-reviewed journals and congresses in a universally accepted way. The number of records of an HEI in the SCOPUS database can be considered as a direct measure of an institution's productivity and of the overall quality of its research. The approach we used is in line with Ecuador's government, which has recently chosen this standard to evaluate the publication efforts of institutions, programs and researchers. Additionally, the SCOPUS database system enables one to compare the publication activity of Ecuador's HEIs in peer-reviewed journals to the publication activities of other, global HEIs.

At the end of 2015, Ecuador's overall record in SCOPUS consisted of articles in journals/proceedings generated by 41 institutions (18 universities/polytechnic schools, 9 hospitals and 14 research institutes). Ecuador's cumulative record in the SCOPUS database was 5,862 registrations, that were distributed as follows: the total number of registrations of the 18 listed universities in the database amounted to 4,574 records $(\mathrm{AVG}=254.1$; $\mathrm{STDEV}=240.9 ; \mathrm{MIN}=25 ; \mathrm{MAX}=925)$; the nine hospitals contributed 737 records to Ecuador's score (AVG=81.9; STDEV=43.9; $\mathrm{MIN}=21$; $M A X=137)$, and the research institutes produced 551 records $(A V G=39.4 ; S T D E V=43.6 ; M I N=5$; 
MAX=167). These data not only illustrate that Ecuador's total historic record in SCOPUS is low, but also that most HEIs, (49 out of 67 institutions or $73 \%$ ) do not contribute to the country's publication visibility at international level. In other words, the main mission of most Ecuador's public and private HEIs at the end of 2015 was still focused on education, and the research profiles of the 18 HEIs with records in SCOPUS could only be in a "transitional phase" at best.
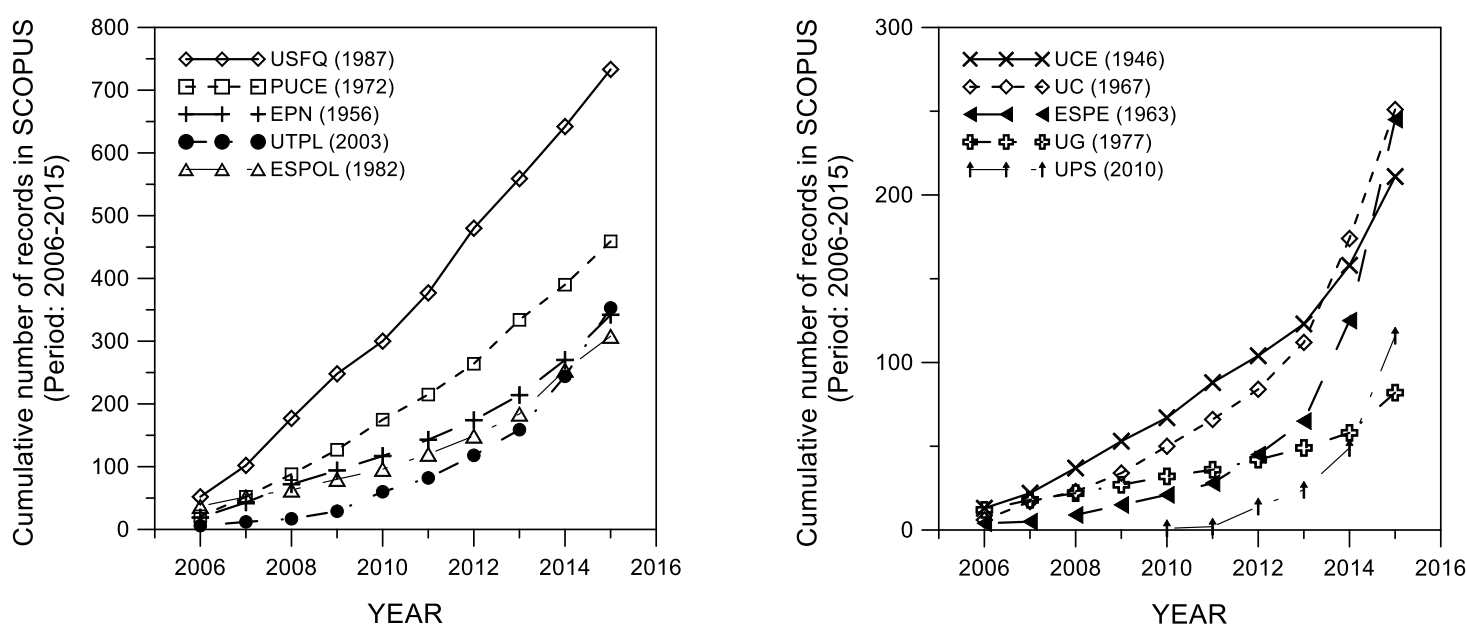

Figure 1. Cumulative number of records of the top-10 Ecuadorian universities ${ }^{1}$ in SCOPUS in the period 2006-2015. Year in brackets after acronyms is the year the institution acquired its first record in SCOPUS.

Figure 1 depicts the evolution of the SCOPUS records of the top-10 Ecuadorian HEIs during the period 2006-2015. The results of these ten universities were split into two groups, in descending order of their cumulative records in SCOPUS (See Figure 1), with adjustments made on the Y-axes. These ten universities are six public (EPN, ESPOL, UCE, UC, ESPE, UG) and four private (USFQ, PUCE, UTPL, UPS) institutions. The publication records of the universities before 2006 were not included, as the years that a first HEI record was registered in the SCOPUS database vary greatly from institution to institution (from 1946 (UCE) to 2010 (UPS)), and because of virtually absent registration levels before 2006.

In the beginning of the 10-year period of analysis, the Universidad de San Francisco de Quito (USFQ) and the Pontificia Universidad Católica del Ecuador (PUCE), both private institutions, had a higher publication record in SCOPUS than the other 8 HEIs. However, the change in the steepness of the cumulative curves, as depicted in Figure 1, clearly reflects that the output in terms of research papers published in the second half of the 10-year period was growing rapidly in EPN, ESPOL and UG and even more rapidly in UTPL, UC, ESPE, UCE and UPS.

\section{THE BACKLOG IN WRITING CULTURE OF ECUADOR's HEIS}

A way to assess the publication visibility of Ecuador's HEIs with respect to international universities is by comparing their publication records in the SCOPUS database. In 2015, the average number of international publications of the top-10 universities in Ecuador was 74 (STDEV=28, MIN=29, $M A X=109$ ). If we compare this for example with the average records of the top-10 universities in Chile,

1 USFQ: Universidad San Francisco de Quito; PUCE: Pontificia Universidad Católica del Ecuador; EPN: Escuela Politécnica Nacional; UTPL: Universidad Técnica Particular de Loja; ESPOL: Escuela Superior Politécnica del Litoral; UCE: Universidad Central del Ecuador; UC: Universidad de Cuenca; ESPE: Escuela Politécnica del Ejército; UG: Universidad de Guayaquil; UPS: Universidad Politécnica Salesiana. 
Argentina and Colombia, countries in which the university reform movement clearly resulted into a modernization of the higher education system, those universities had average records of 830 (STDEV=705, MIN=335, MAX=2290) in Chile, 572 (STDEV=729, MIN=68, MAX=2423) in Argentina, and 473 (STDEV=489, MIN=78, MAX=1666) in Colombia at the end of 2015. In 2015, the publication visibility in SCOPUS of the top-10 universities in Chile, Argentina and Colombia was 11.2, 7.7 and 6.4 times larger than the average record of Ecuador's top-10 universities. Noticeable for Chile, Argentina and Colombia is that the better average records are largely due to the records of their top-2 universities, which was not the case for Ecuador's HEIs where publication levels were more equally distributed. This delay in publication output of Ecuador's HEIs is mainly because Ecuador's government and universities have long emphasized excellence in teaching and disregarded the development of the universities' research capacity (Blume, 2015). Only very recently, and under heavy government pressure, have Ecuador's HEIs hesitantly started the transition from a "teaching-focus" to a "teaching supported by research focus."

Using historical data in the SCOPUS database it is possible to reconstruct the delay in publication visibility of Ecuador's HEI as compared to universities in other parts of the world. To this end, the publication trends of a limited number of universities in South America (UCV: Universidad Católica de Valparaiso; UDELAR: Universidad de la República Uruguay; UNAL: Universidad Nacional de Colombia; UNMdP: Universidad Nacional de Mar del Plata; UNS: Universidad Nacional del Sur; USC: Universidad de Santiago de Chile) and Western Europe (JLU: Justus-Liebig-Universität Gießen; KUL: Katholieke Universiteit Leuven; UCL: Université Catholique de Louvain; UG: University of Ghent; UPSUD: Université Paris-Sud; UV: Vrije Universiteit Amsterdam) were analyzed when those universities were in a process similar to the transformation process Ecuadorian universities are undergoing today. The criteria used for the selection of universities in this comparative analysis was that qualifying universities should, in the transition period from "teaching" to "teaching and research," reflect similar publication trends in the SCOPUS database as the retained Ecuadorian HEIs over an 18year period (the time frame in which publication records existed for Ecuadorian HEIs). For the reconstruction of the trends in SCOPUS we used a Box-Whisker plot approach. Figure 2 shows the evolution of the variation in publication records in SCOPUS (minimum, maximum, median, lower quartile, and upper quartile) of the six leading Ecuadorian HEI's for the period 1997-2015. Using the same approach, the variation in publication records in SCOPUS of 6 South American and Western European universities was drawn for an 18-year period as well. By trial and error, we went back in time to the period 1978-1996, to obtain a match between the evolutions in Box-Whisker plots of the 6 Ecuadorian and South American HEIs. Applying an analogous approach for the selected Western European universities, similarity in the evolution in Box-Whisker plots depicting the annual variation in publication records in SCOPUS was obtained when we used data of the period 1949-1967.

Figure 2 presents the Box-Whisker plots for the 6 Ecuadorian universities (black dotted line), South- American (red dotted line) and Western-European universities (blue solid line). The similarity between the lines connecting the medians of the distribution illustrates that the writing cultures or productivity in Western-European universities some 50 years ago, and in South-American universities some 20 years ago were very like the present situation in Ecuador's HEIs. This comparison only holds for the median of each regional group of universities used in the analysis. The level of the median stands for a total institutional record in the SCOPUS database system and represents the output of an institution that is composed of faculty/research groups that publish and those who do not publish. Unfortunately, the latter are a majority in Ecuador's universities.

The publication trends in Ecuador's top universities are reflective of similar trends in other countries in the past, but similarly to what happened in these countries Ecuador is since 2007 putting in place efforts to enhance its scientific publication visibility. Unfortunately, Ecuador's overall scientific productivity in terms of published research articles at the international level can only be characterized as insignificant and amounts to $0.02 \%$ of the world's total output of research papers (Morales, 2013). 


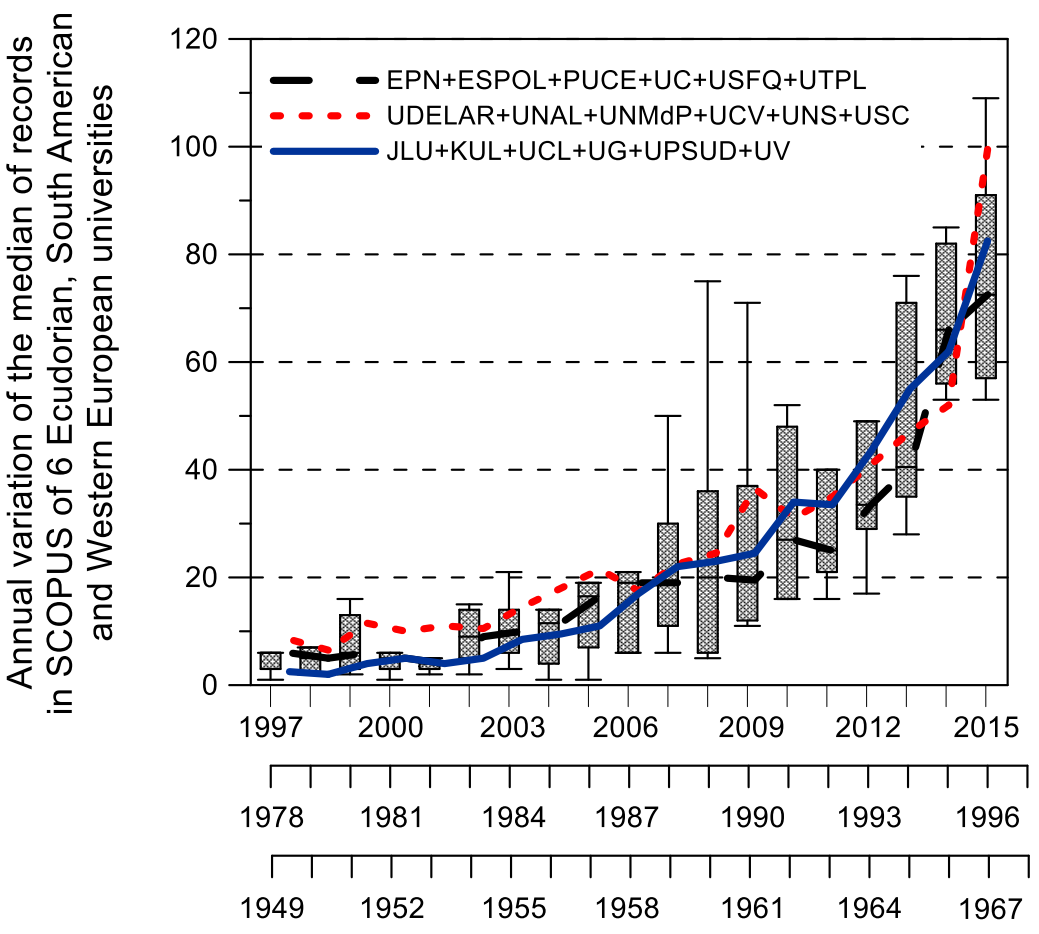

Figure 2. Annual variation of the records in SCOPUS of 6 Ecuadorian universities (Box-Whisker plot), and comparison of the median of the records in SCOPUS of 6 Ecuadorian, South American and Western European universities (dotted black, red and solid blue line) ${ }^{2}$.

\section{CAUSES OF BACKLOG IN PUBLICATION ACTIVITY}

There are a variety of reasons that have caused the low publication performance of Ecuador's HEIs and the origin of those reasons lies in the past. Historically, education in Ecuador was anchored in the ruling elites of society and in the Catholic Church, and was an outgrowth of Spanish colonization. Institutions of higher learning, as stipulated in the French model, emerged in Latin America late because of a lack of strong central governments, a weakly-structured society, and poorly developed economies (Schwartzman, 1993 \& 1999). This is the main reason why Hispanic-American universities were called "Academias señoriales" (Lordly academies) or "Virreinatos del conocimiento" (Viceroyalties of knowledge) for a long time (Tünnermann, 1996). While the University Reform Movement of the 1920s was a strong challenge to traditional university structures and led to a first modernization and massification of higher education, its impact in most Latin American countries was strongly curtailed by conservative socioeconomic structures (Arocena \& Sutz, 2001). In response to large scale social, economic and cultural changes, true massification of higher education in Latin America only occurred in the 1960s (Schwartzman, 1999). The driving forces behind this second wave of modifications were, among others the population growth in the large cities, the expansion and improvement of basic and secondary education system, the new skills required by industry and services, and a gradual increase in

2 EPN: Escuela Politécnica Nacional; ESPOL: Escuela Superior Politécnica del Litoral; PUCE: Pontificia Universidad Católica del Ecuador; UC: Universidad de Cuenca; USFQ: Universidad San Francisco de Quito; UTPL: Universidad Técnica Particular de Loja

UDELAR: Universidad de la República Uruguay; UNAL: Universidad Nacional de Colombia; UNMdP: Universidad Nacional de Mar del Plata; UCV: Universidad Católica de Valparaiso; UNS: Universidad Nacional del Sur; USC: Universidad de Santiago de Chile.

JLU: Justus-Liebig-Universität Gießen; KUL: Katholieke Universiteit Leuven; UCL: Université Catholique de Louvain; UG: University of Ghent; UPSUD: Université Paris-Sud; UV: Vrije Universiteit Amsterdam. 
welfare and public services. Unfortunately, in Latin America, and more in particular in Bolivia, Peru and Ecuador (Weise \& Laguna, 2008) higher education changed very little, and this limited effect of the reformation is largely responsible for the overall weak profile and structure of Ecuador's HEIs (Tünnermann, 1996). The main mission of Ecuador's HEIs remained the education of professionals, which was accompanied by poor formalization of the teaching career, an expansion and strengthening of the autonomy of the colleges, a central administrative and management structure unable to resolve institutional problems, a low academic and scientific profile, and a weak connectivity with society at large (Cevallos Estarellas \& Bramwell, 2015).

The negative consequences of the absence of research-related activities in Ecuador's HEIs were already communicated in the 1950's (Cueva Tamariz, 1958) and ensuing sporadic and dispersed efforts to improve the situation did not lead to the establishment of solid investigation and research traditions, a feature that is common in the HEIs in other Latin American countries, such as Brazil, Argentina, Chile and Peru (Vessuri, 1997). Sempértegui (1990) examined the research engagement of Ecuador's HEIs at the beginning of the 1990s and pointed out that idiosyncratic traits hindered the overall development of a scientific culture. In Ecuador's HEIs research did not receive, and had never received, the same attention and institutional support as their other missions, and at the onset of the $21^{\text {st }}$ century this poor research profile remained very much in place. Characterized by high dispersion and lack of prioritization (Sempértegui, 1990), science in Ecuador could not meet the premises posed for scientific research (IESALC, 2006) in any meaningful way, such as the creation of new wealth, finding solutions for societal problems, and the provision of basic insights for the making of more sound and effective decisions by political, social and economic actors. Instead of continuing to borrow foreign knowledge and expertise, Ecuador, and its HEIs, should heavily invest in the stimulation of innovation, invention and creativity, considered the major drivers of growth and advancement (West, 2000).

A survey conducted at the Universidad de Cuenca in 2014 (Feyen, 2015), in which 37\% of all faculty members and researchers participated, revealed that a large majority of the academic staff (71.5\%) considered itself a teacher. Although most respondents to the survey believed a professor's first mission was teaching, the awareness that academics should be involved in research is slowly growing, primarily in response to the introduction of the Ley Orgánica de Educación Superior (Higher Education Law) in 2010 and the Reglamento de Carrera y Escalafon (Law on Seniority and Salaries) by the government in 2012. These laws made higher education free to all citizens, changed the career paths and research expectations for professors, and centralized many budgetary and administrative functions under the central government.

HEIs were slow to respond to government pressures as illustrated by the fact that the University Council of the University of Cuenca only approved the Reglamento Interno de Carrera y Escalafon at the beginning of 2015, three years after the government had introduced the law. The introduction of both laws had led to a complete shift in the mentality of the academic corps. Faculty members are now forced to dedicate time to research in accordance with their positions. Whereas the Escalafon stipulates a range of hours that faculty members should dedicate to teaching, the preparation of classes, managerial tasks, research, and outreach activities, there is still a tendency among institutions to overload faculty with teaching assignments, under the justification that it takes time to adjust internal regulations and the situation on the ground to the new legislation during a transition period. The survey mentioned above (Feyen, 2015) revealed that faculty still teaches more hours than stipulated in the Escalafon today. A general observation made by faculty members in the survey came down to the following: "We do not have time to dedicate to research for the simple reason that teaching, the time for the preparation of classes, and the time lost in curriculum meetings and complicated and cumbersome administrative activities absorb the official time that full-time (40 hrs/week), half-time (20 hrs/week) and part-time (less than $20 \mathrm{hrs} /$ week) faculty should be present in the institution."

Whereas time constraints are the most dominant factor hindering the faculty's involvement in research, other factors limiting a dedication to research are a lack of ability to do research, a lack of knowledge of the relevant literature, the individualistic nature of academics which hinders their willingness to work in teams, limitations in research infrastructure and funding, and the crippling bureaucratic regulations that exist in the HEIs and that are based on a mistrust, rather than a trust, of the university's constituents. In general, academic staff members have very limited awareness of the status of knowledge in their fields, because of a limited ability to speak and read the English language, limited 
access to digital journal databases, and problems in reading and analyzing research papers. Consequently, research proposals are weak and poorly formulated and often amount to nothing more than a reinvention of the wheel.

Staff with research experience is still a minority. Whereas the LOES stipulates that $70 \%$ of the full professors should possess doctoral degrees by 2017 , the reality is very different. At the University of Cuenca, for instance, 107 (8.7\%) out of the 1231 full-, half- and part-time academic faculty members hold $\mathrm{PhD}$-degrees. Of those, 51 have tenured positions and 56 are contracted (part-time). Staff members with research master's degree amounts to $16.8 \%$, and the rest of the academic staff either possesses a professional master's degree $(37.3 \%)$, a diploma or specialization degree $(19.4 \%)$ or undergraduate degree $(16.8 \%)$. Thanks to the availability of study grants made available by the government, which enable those with the right qualifications to acquire MSc- and/or PhD-degrees abroad, the number of staff holding higher academic qualifications will increase. Since 2007, SENESCYT (http://programasbecas.educacionsuperior.gob.ec/) provided financial support to 10,000 citizens to pursue advanced degrees. The only drawback is the unrealistic timeline set forth by the government: it is impossible that $70 \%$ of the full-time professors will possess doctoral degrees by 2017 . Therefore, an increasing number of faculty members seek to acquire doctoral degrees at institutions where the requirements for an accredited doctoral degree that teaches them how to conduct research are modest to low. This is already visible at the University of Cuenca: of the $107 \mathrm{PhDs}$ at the university only $1 / 3$ has published one or more publications in peer-reviewed journals registered in SCOPUS (Feyen, 2015). Most of their work continues to be published locally in non-indexed journals, or in journals with low impact factors.

\section{POSSIBLE SOLUTIONS}

Traditionally, teaching has been an academic activity that is executed by one lecturer in one discipline. Ways to reduce the teaching load without jeopardizing the educational quality are the joint organization of similar subjects over the boundaries of schools and faculties, a potential avenue that would enable staff deployment more efficiently, offering unique opportunities to reduce the overall teaching load of faculty members, so that they would no longer have the excuse that a lack of time is preventing them from dedicating time to research. Unfortunately, the culture of working together between colleges and departments in the achievement of common goals, such as the improvement and joint organization of undergraduate and postgraduate programs of study, is lacking. Team teaching, in which a group of lecturers work together, and blended teaching, whereby the docent uses different teaching methods including online components on top of the classical classroom setting, might be additional approaches to optimize and reduce staff's teaching load. Although several models of effective co-teaching and flipped classroom exist (Baeten \& Simons, 2014; Dangi et al., 2015; Higgins \& Litzenberg, 2015; Rodriguez, 2016), those concepts have not caught on in Ecuador's HEIs.

The attitude of working together is also lacking in research. Given the complexities of today's problems it is increasingly unlikely that a single faculty member or researcher can develop appropriate and cost-effective solutions and get his/her findings published in peer-reviewed journals. Teamwork is needed for the development of new knowledge, even teamwork among faculty members belonging to different disciplines. The formation of research groups around specific and relevant societal problems should be stimulated, not only enabling the development of solutions and the reporting of the research results in peer-reviewed journals and resulting in an overall improvement of the institution's ranking, but also because several know more than one. Colleagues can complement each other in their research efforts: whereas one might be strong in his/her conceptual skills, others excel in methodology and analysis.

Just as it is important that professors and researchers work together and form meaningful and sustainable research groups, it is equally important that administrative units within the university with direct and indirect impact on the research status of the institution consult and work together to align policies and measures that empower collaboration. A clear example of this lack of collaboration that directly affects the University of Cuenca's publication visibility are the numerous, low quality college- 
based and institutional journals that exists, each with its own editorial team and format, yet not receiving enough contributions to maintain a regular publication frequency. Only a few of these are indexed in Latindex and the visibility of most of these is insignificant. Why are editorial teams within the HEI and even between HEIs not cooperating to produce a limited number of sustainable research journals at regional and national level, meeting the quality criteria for indexation in SCI, SCOPUS or any other well-recognized indexing system? If the publication invisibility at international level is a concern of the Ecuadorian government, SENESCYT, CES and CEAACES should join forces and take the right initiatives to make this happen.

Other elements impeding faculty's research efficiency are a limitation in research infrastructure and funding. The infrastructure of most universities still reflects their educational missions; they are a conglomerate of small lecture halls and classrooms, very much similar in concept to the infrastructure of secondary schools. Laboratories, scientific equipment and staff offices, except in a limited number of institutions, are in embryonic state. In the best-case scenarios, several faculty members share one office, and a limited number of research groups which acquired international funding or obtained a research grant from SENESCYT have invested in modern research equipment. In general, however, the state of the equipment in didactic laboratories is often distressing.

As opposed to the period before 2007, the financial situation of the public and private universities has improved and the government has initiated various programs to enhance the transition of its universities from "teaching-only" to "teaching and research." Examples are the improvement of the institutions' financial situations, the growth in the number and the quality of the available scholarship programs, the initiation of the PROMETEO program enabling universities to hire qualified overseas experts to provide research assistance in the transition process, the availability of research grants, and the creation of a sabbatical leave system.

However, the improvement of the financial situation of Ecuador's public institutions went hand in hand with an increasing interference and control of the government, resulting in a constant fight for political control between what Schwartzman (1993) calls the "oligarchies" and the state. University authorities have continuously resisted the state curtailing their autonomy, which was sacred to them. It is certainly true that these new financial rules and regulations have placed the institutions at the mercy of the central government for funds (Einaudi, 1963) and it is understandable that the government wants to control how public resources are used. Unfortunately, the state intervention was accompanied by an expansion of the institutions' bureaucratic operations which negatively affected most institutional facets of the HEIs. It is not uncommon for a research team in the initial phase of a 2-year research project to lose up to 6-months in arranging all administrative and legal matters that are involved in the overseas procurement of equipment or biochemical products and staff recruitment, with the result that many research projects fail to achieve their objectives within the projected project duration and for the dissemination of results in a research paper that is eligible for publication in an indexed journal. Universities and the state should jointly develop solutions to end crippling bureaucratic policies and measures and redefine the definition of autonomy, which has been centered on giving universities the freedom to define their own curricula and manage their own budgets without interference from a central government since the Argentine university reform of 1918. Autonomy of the institution should be in line with the role of the university in society in the $21^{\text {st }}$ century, and encompass the academic freedom required for the achievement of its objectives in close cooperation with society and in harmony with the requirements of funding agencies, the state and the private sector.

If Ecuador's HEIs can demolish the hindering boundary conditions, the question than can be raised if this will then automatically result in an increased research output? The answer to this question is probably no, for the simple reason that an increase in publication visibility requires a change in mentality of a dominant conservative academic community which grew up in a time when teaching was the HEI's main mission. Today, HEIs should be producers of knowledge, and not just passing knowledge from one generation to another. The latter requires that faculty members become real academics, active in teaching, research and extension, continuously updating and extending their knowledge, able and willing to collaborate. And since a shift in mentality is a long-term process, a substantial increase in Ecuador's publication visibility at the international level will take several years. 


\title{
CONCLUSIONS
}

The first quarter of the $21^{\text {st }}$ century is characterized by continuing demographic expansion, unbalanced growth of economic development, a technological revolution with an expanding role in our everyday lives, increasing economic and social inequality, and degradation of the environment. A new generation of researchers will play, and must play, an active role in the development of innovative solutions to today's socio-economic and ecological problems. Universities should prepare them for this task, yet in Ecuador that will not happen if the educational paradigms that dominated the previous century are maintained. Universities should change their pedagogical models and contribute to society in a more effective way by enhancing knowledge production (Duderstadt, 1999; Denman, 2005; Winckler, 2009). Failing to meet the needs for a new generation of students who are about to enter the global knowledge economy will undermine the survival of the universities. The pedagogical system of modern universities should be turned into collaborative learning that embraces discovery (Tapscott and Williams, 2010). New graduates, in addition to having high-level skills and technical competence in their disciplinary fields, should possess a range of soft skills that support and facilitate their entrepreneurial, coordinating and management roles in society (Brew \& Boud, 1995; Kenny, 1998; Kolb, 1983, Nuchwana, 2012; Ramsden \& Moses, 1992; Savery, 2006). Ecuador should turn its universities into centers of collaborative learning and research and into campuses where young people get a chance to "grow up" (Tapscott \& Williams, 2010). Furthermore, HEIs ought to place a strong emphasis on joint knowledge production, whereby researchers, policy makers and other societal actors work together in the search for socio-economically relevant and sustainable solutions (Hegger \& Dieperink, 2015).

Universities need to use their academic autonomy to make this happen. Given the recent decline in Ecuador's economic revenues, it is to be expected that its HEIs must organize and manage their activities with fewer resources, while it is likely that the influx of more students will continue. This situation should stimulate HEIs to introduce innovative changes resulting in a more efficient use of its human and financial resources, turning its outdated educational system of instruction into a system of student-focused learning and discovery, and be more entrepreneurial and affordable in collaborative knowledge production (Lee, 2007). Universities are expected to have the brains and vision to makes this happen; it only requires a drastic change in the mentality of the oligarchies and of the faculty and will involve a breaking down of the walls that separate academics, schools and colleges within the institutions, and that separate Ecuador's institutions of higher education from the rest of the world (Tapscott \& Willimas, 2010). As Barr \& Tagg (1995) state, in the case of Ecuador's HEIs, changing paradigms imply doing everything differently.

\section{ACKNOWLEDGEMENTS}

This work was supported by DIUC, the Central Research Office of the University of Cuenca, Cuenca, Ecuador.

\author{
ABBREVIATIONS \\ CES: Consejo de Educación Superior \\ CEAACES: Consejo de Evaluación, Acreditación y Aseguramiento de la Calidad de la Educación \\ Superior \\ DIUC: Dirección de Investigación de la Universidad de Cuenca \\ LDC: Least Developed Countries \\ OECD: The Organization for Economic Co-operation and Development \\ SENESCYT: Secretaría de Educación Superior, Ciencia, Tecnología e Innovación
}




\section{REFERENCES}

Arocena, R., J. Sutz, 2001. La universidad latinoamericana del futuro. Tendencias-EscenariosAlternativas. México D.F., México: Editorial UDUAL.

Baeten, M., M. Simons, 2014. Student teachers' team teaching: Models, effects, and conditions for implementation. Teaching and Teacher Education, 41, 92-110.

Barr, R.B., J. Tagg, 1995. From teaching to learning: A new paradigm for undergraduate education. Change, 27(6), 12-25.

Blume, S., 2015. University transformation and regional development. Maskana, 5(1), 15-31.

Brew, A., D. Boud, 1995. Teaching and research: Establishing the vital link with learning. Higher Education, 29, 261-273.

Cano, V., 1994. International visibility of periodicals from Ireland, India and Latin America. Knowledge, Technology \& Policy, 6(3), 55-78.

Cevallos Estarellas, P., D. Bramwell, 2015. Ecuador, 2007-2014: Attempting a radical educational transformation. In: Schwartzman, S. (Ed.), Education in South America, pp. 329-361. London: Bloomsbury Academic.

Chalmers, I., 1990. Underreporting is scientific misconduct. Journal of the American Medical Association, 263, 1405-1408.

Clark, B.R., 1997. The modern integration of research activities with teaching and learning. Journal of Higher Education, 68(3), 241-255.

Cueva Tamariz, C., 1958. Panorama de la Educación en el Ecuador. Anales de la Universidad de Cuenca, XIV(4), 359-374.

Dahdouh-Guebas, F.J., R. Ahimbisibwe, R. Van Moll, N. Koedam, 2003. Neo-colonial science by the most industrialized upon the least developed countries in peer-reviewed publishing. Scientometrics, 56(3), 329-343.

Dangi, R.B., A. Bhore, R. Bhinde, 2015. Team teaching of higher mathematics. Golden Research Thoughts, 5(2), 1-5.

Denman, B.D., 2005. What is a University in the 21st Century? Higher Education Management and Policy, 17(2), 9-26.

Duderstadt, J.J., 1999. The Future of Higher Education: New Roles for the 21st-Century University. Issues in Science and Technology Online. Available at http://milproj.dc.umich.edu/ publications/newroles/download/newroles.pdf, 7 pp.

Einaudi, L., 1963. University autonomy and academic freedom in Latin America. Available at http://scholarship.law.duke.edu/cgi/viewcontent.cgi?article=2973\&context=lcp, pp. 636-646.

Erftmeijer, P., A.K. Semesi, C.A. Ochieng, 2001. Challenges for marine botanical research in East Africa: Results of a bibliometric survey. South African Journal of Botany, 67, 411-419.

Fang, F.C., A. Casadevall, 2015. Competitive Science: Is competition ruining Science? Infection and Immunity, 83(4), 1229-1233.

Feyen, J., 2015. Vinculación de la Docencia con la Investigación. Dirección de Investigación, Universidad de Cuenca, Ecuador, Vol. 5, 115 pp.

Gaillard, J., 1991. Scientists in the Third World. Lexington, KY: The University Press of Kentucky, $190 \mathrm{pp}$.

Gaillard, J., 2000. Monitoring and evaluation system for impact assessment (MESIA). Conceptual framework and guidelines. Report No. 1. Stockholm: IFS, 38 pp.

Gibbs, W.W., 1995. Lost science in the third world. Scientific American, pp. 92-99.

Hegger, D., C. Dieperink, 2015. Joint knowledge production for climate change adaptation: What is in it for science? Ecology and Society, 20(4), 1-13.

Herxheimer, A., 1993. Publishing the results of sponsored clinical research. British Medical Journal, 307(20), 1296-1297. 
Higgins, L.M., K.K. Litzenberg, 2015. Transferring experience through team teaching: The chance of a lifetime. College Teaching, 63(3), 105-111.

IESALC, 2006. Informe sobre la educación superior en América Latina y el Caribe: 2000-2005. La metamorfosis de la educación superior. Instituto Internacional de la UNESCO para la Educación Superior en América Latina y el Caribe (IESALC), 351 pp.

Jha, A., 2012. False positives: fraud and misconduct are threatening scientific research. The Guardian, 13 September 2012. Available at https://www.theguardian.com/science/2012/ sep/13/scientific-research-fraud-bad-practice.

Kaur, J., E. Ferrara, F. Menczer, A. Flammini, F. Radicchi, 2015. Quality versus quantity in scientific impact. Journal of Informetrics, 9, 800-808.

Kenny, R.W., 1998. Reinventing Undergraduate Education: A Blueprint for America's Research Universities. Carnegie Foundation for the Advancement of Teaching. Available at http://www.niu.edu/engagedlearning/research/pdfs/Boyer_Report.pdf, 54 pp.

Kilonzo, M.S., K. Magak, 2013. Publish or perish. International Journal of Sociology, 43(1), 27-42.

Kolb, D.A., 1983. Experiential Learning: experience as the source of learning and development. New York, NY: Prentice Hall.

Lee, P.L., 2007. Teaching-research nexus at the University of South Australia. Available at http://w3.unisa.edu.au/ academicdevelopment/engagement/documents/discussion.pdf, $11 \mathrm{pp}$.

Morales, J., 2013. La Universidad investigadora. Revista de la Facultad de Ciencias Médicas, Universidad de Cuenca, 31(1), 68-73.

Nuchwana, L., 2012. How to link teaching and research to enhance students' learning outcomes: Thai University Experience. Procedia - Social Behavioral Sciences, 69, 213-219.

Raina, D., S.I. Habib, 1994. Patronage, competition and rivalry: The structure of scientific exchanges in the age of colonialism. ORSTOM/UNESCO Conference on the $20^{\text {th }}$ Century Science: Beyond the Metropolis, 19-23 September, Paris, France.

Ramsden, P., I. Moses, 1992. Associations between research and teaching in Australian Universities. Higher Education, 23, 273-295.

Rodriguez, J.E., 2016. A massively flipped class: Designing and implementing active learning information literacy instruction for a large enrollment course. Reference Services Review, 44(1), 4-20.

Savery, J.R., 2006. Overview of problem-based learning: Definitions and distinctions. IJPBL, 1(1), 9-20.

Schwartzman, S., 1993. Policies for higher education in Latin America: the context. Higher Education, 25, 9-20.

Schwartzman, S., 1999. Latin America: National responses to world challenges in higher education. In P. G. Altbach \& P. McGill Peterson (Eds.). Higher Education in the $21^{\text {st }}$ century: Global Challenge and National Response. IIE Research Report No. 29, Chapter 6, pp. 47-57.

Sempértegui, J., 1990. Estado actual de la ciencia y tecnología en el Ecuador. Available at http://repositorio.educacionsuperior.gob.ec//handle/28000/993.

Tapscott, D., A.D. Williams, 2010. Innovating the 21st-century university. EDUCAUSE review (www.educause.edu/er), pp. 17-29.

Tünnermann, C., 1996. Conferencia introductoria. En Conferencia regional sobre políticas y estrategias para la transformación de la educación superior en América Latina y el Caribe. Vol. 18, pp. 85-111, La Habana, Cuba. Available at http://unesdoc.unesco.org/images/0014/001493/ 149330so.pdf.

Vessuri, H., 1997. Investigación y desarrollo en la universidad latinoamericana. Revista Mexicana de Sociología, 59(3), 131-160.

Weise, C., J.L. Laguna, 2008. La educación superior en la región Andina: Bolivia, Perú y Ecuador. Avaliação, Campinas: Sorocaba, SP, 13(2), 425-450. 
West, J., 2000. The mystery of innovation: Aligning the triangle of technology, institutions and organization. Australian Journal of Management, 26(Special Issue), pp. 21-43.

Winckler, G., 2009. Universities in the 21st century. IOS Press, 14 pp. 